CZASOPISMO INŻYNIERII LADDOWEJ, ŚRODOWISKA I ARCHITEKTURY

JOURNAL OF CIVIL ENGINEERING, ENVIRONMENT AND ARCHITECTURE

JCEEA, t. XXXII, z. 62 (3/II/15), lipiec-wrzesień 2015, s. 315-324

\author{
Witold NIEMIEC ${ }^{1}$ \\ Feliks STACHOWICZ ${ }^{2}$ \\ Tomasz TRZEPIECIŃSKI ${ }^{3}$ \\ Leszek KEPPA ${ }^{4}$ \\ Marek DZIURKA ${ }^{5}$
}

\title{
SMALL-SCALE HARVESTING MACHINERY FOR SHORT ROTATION WILLOW COPPICE
}

\begin{abstract}
Mechanization in the harvesting of short rotation willow coppice is a prerequisite for the areal expansion of short rotation coppice cropping. In the article new machines for small-sized plantations of energetic plants have been presented. The prototypes of machines were manufactured by R\&D Centre INVENTOR sp z .o.o and SIPMA S.A in Lublin in cooperation with the Rzeszow University of Technology. The advantage of proposed solutions is their uncomplicated construction which is connected with low production cost and simple machine operation. The energy-crop harvesting machines are competitive with the world's leading manufacturers of machinery. The chipping units of front mounted harvester and side harvesting machines are power-take-off driven. The cutting header for the harvesters uses circular saws driven by hydraulic engines.
\end{abstract}

Keywords: biomass harvesting, willow, harvester, RES, short rotation coppice

\section{Introduction}

Short rotation coppice (SRC) refers to a fast-growing, high yielding woody crop that is harvested every two to five years [19]. The short rotation term means the harvesting frequency: every 2-3 years. The two dedicated SRC crops

\footnotetext{
${ }^{1}$ Witold Niemiec, Rzeszow University of Technology, Al. Powstańców Warszawy 12, 35-959 Rzeszów, tel. 17 8651504,wniemiec@prz.edu.pl.

${ }^{2}$ Feliks Stachowicz, Rzeszow University of Technology, Al. Powstańców Warszawy 12, 35-959 Rzeszów, tel. 17 8651538, stafel@prz.edu.pl.

3 Autor do korespondencji/Corresponding author: Tomasz Trzepieciński, Rzeszow University of Technology, Al. Powstańców Warszawy 12, 35-959 Rzeszów, tel. 178651714 , tomtrz@prz.edu.pl.

${ }^{4}$ Leszek Kępa, SIPMA S.A., ul. Budowlana 26, 20-469 Lublin, tel. 81 7445071, info@sipma.pl

${ }^{5}$ Marek Dziurka, R\&D Centre INVENTOR sp. z o.o., ul. Ciepłownicza 4, 20-469 Lublin, tel. 81 4414146,mdziurka@rndcentreinventor.pl.
} 
belong to the plant family Salicaceae and include genera: poplar and willow. The average commercial willow yields of 8-10 over dry tonnes per hectare per year are attainable in Europe and generally is greather in the second harvest rotation compared to the first due to overall increase in shoots per stool and stem diameter between harvests $[1,19]$.

Willow in SRC should be harvested during the period between leaf fall and emergence, when the moisture content of the wood is about $55 \%[16,19]$. Willow reaches optimal yield under a 3-year cutting rotation. In general three harvesting methods have been identified:

- chip harvesting (cut-and-chip method) using tractor-mounted equipment or self-propelled machines,

- billet harvesting (cut-an-billet method): manually using stationary equipment, or using self-propelled big machines, such as Austoft 8800,

- whole-shoot harvesting: using tractor-drawn equipment or self-propelled machines; manually or motor-manually, using chainsaw or brush cutter.

Although different biomass harvesters have already been developed, mainly two harvesting approaches have been developed for short rotation woody crops, i.e. the harvest-and-chip system [17] and the harvest-and-storage system [13, 14]. Tractor-mounted cut-and-chip equipment is cheaper that self-propelled harvesters, but has a lower productibility. They are equipment with a different cutting headers, usually disc saws. A cut-and-chip machine can use a tractor-trailer, which travels alongside the harvester. Chips produced using cut-and-chip methods are unsuited for long term storage because of very wet [3]. Self-propelled harvesters tend to be much heavier that tractor-mounted machines. This can pose problems of soft terrain, where machines compress the top soil. In these conditions, the harvesters with caterpillar tracks can be used. The machines for cut-and-billet systems are capable of producing standard $50 \mathrm{~mm}$ chips or by removing some of the knifes and lowering the drum speed, even $200 \mathrm{~mm}$ billets [3].The advantage of this method is that larger particle size is easier to store and dry. The long billets can be re-chipped before they can be used in small-scale boilers.

In the article new machines for small-sized plantations of energetic plants have been presented. The prototypes of front and side harvesting machines were manufactured by R\&D Centre INVENTOR sp. z o.o. and SIPMA S.A. in Lublin in cooperation with the Rzeszow University of Technology. The brief description of our previous work focused on development of new machines for small-scale willow plantations is also presented.

\section{Development of cut-and-billet machinery}

Analysis of properties of different types of renewable energy sources (RES) presented by Trzepieciński et al. [18] lead to a conclusion that woody biomass in East-Central Europe is a RES type characterized by the best synthetic technical and operating parameters. Intensive breeding programs of willow production re- 
sulted in high production rates for a wide range of climates within the EU. An increase of the amount of energetic plant plantation causes the necessity of exploration of new technologies allowing efficient harvesting and further their processing. The deficiency of specialized machines adapted to arable area and their high cost are the following obstacles indicated by potential small producers of biomass which is pointed out by Niemiec et al. [5, 7]. Among the various crops, especially SRC regarded as a strategic resource of wood products are fast-growing and highyielding species which can be managed as a coppice system [15]. Short rotation coppice is a very extensive form of land management in comparison to conventional agriculture, as crops that are harvested in a 2-4 year cycle.

Machines destined for operation in small and medium-sized plantations of energetic plants are characterized by simple construction and they do not require highly skilled workers. In the case of establishing, protective treatments, logging and processing of the biomass in plantation of the energetic plants the farm tractors are basic prime mowers of specialized machines. The majority of developed machines are mounted on a farm tractor using levers of toolbar assembly. For small-scale usage, the whole-shoot cutting method is probably the best. Alternatively for small-scale use, the cut-and-chip method can be used but drying chip requires special dryer and it is very expensive.

Different harvesting machines have already been developed [5-7, 11], mainly two harvesting approaches have been developed for short rotation woody crops, i.e. the stationary billeting system (Fig. 1a) [8] with feeding assembly (Fig. 1b) [9] and harvest-and-billet system (Fig. 2) [10]. In both cases billets are produced from wet stems, collected in an attached trailer or stored as wet chips.

a)

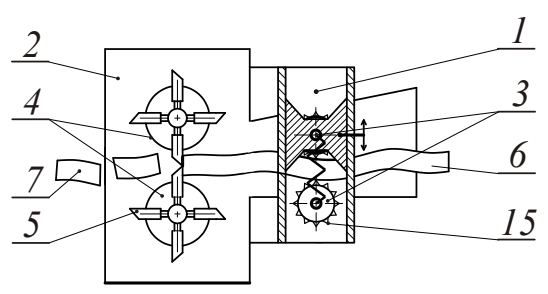

b)

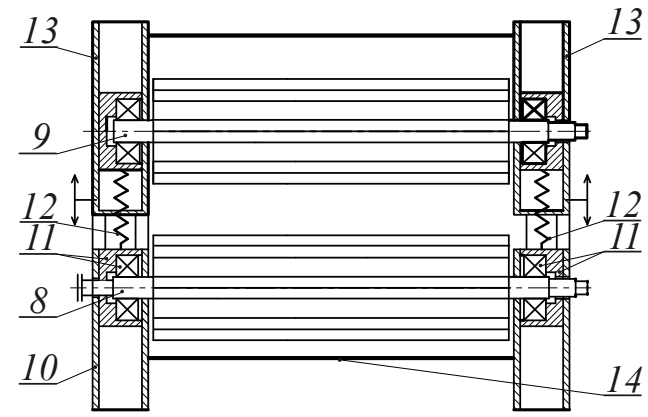

Fig. 1. The chipping (a) and feed (b) assemblies: 1 - feeder, 2 - cutting unit, 3 - feed shafts, 4 cutting heads, 5 - knife, 6 - stem, 7 - billet, 8 - driving shaft, 9 - clamping shaft, 10 frame, 11 - unit of bearing and unidirectional clutch, 12 - compression springs, 13 guides, 14 - guard, 15 - toothed blade

Rys. 1. Rozdrabniarka (a) podajnik (b) schemat montażowy: 1 - podajnik, 2 - jednostka tnąca, 3 -wał podajnika, 4 - głowice tnące, 5 - nóż, 6 - łodyga, 7 - ścinki, 8 - wał napędzający, 9 - wał dociskający, 10 - rama, 11 - mechanizm łożyskowy i sprzęgło przeciwkierunkowe, 12 - sprężyny dociskowe, 13 - obudowa, 14 - osłona, 15 - ostrza zębate 
a)

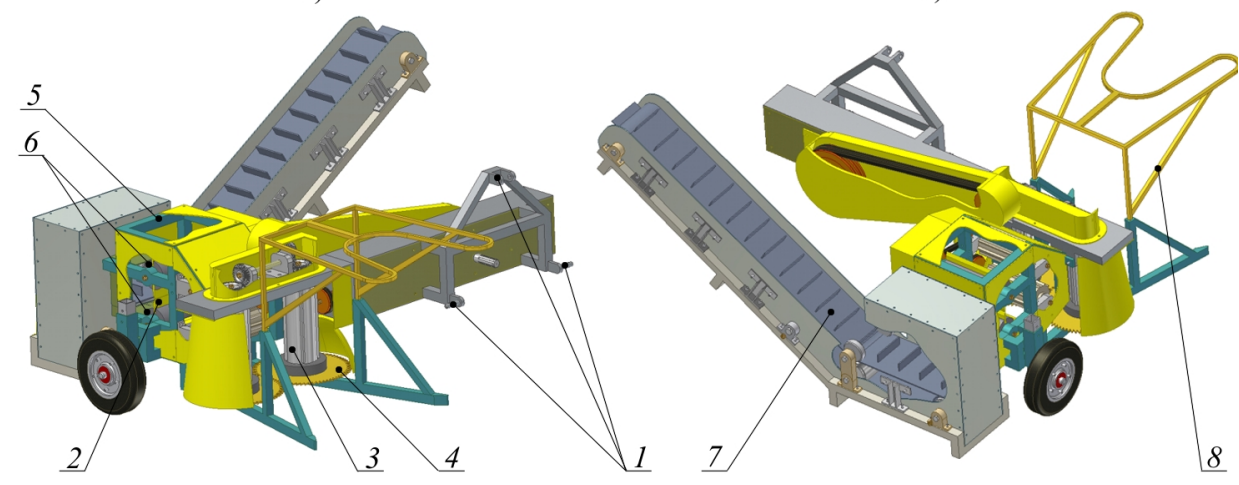

Fig. 2. The in-front (a) and back (b) views of the cut-and-billet harvester model with belt conveyor : 1 - levers of toolbar assembly, 2 - knife, 3 - drum, 4 - circular saw, 5 - billeting assembly, 6 - billeting heads, 7 - belt conveyor, 8 - guiding arm

Rys. 2. Widok z przodu (a) i z tyłu (b) modelu kombajnu kosząco - rozdrabniającego z taśmociągiem: 1 - uchwyt mocujący, 2 - nóż, 3 - bęben, 4 - piła tarczowa, 5 - zbiornik na ścinki, 6 głowica rozdrabniająca, 7 - przenośnik taśmowy, 8 - rama prowadnicy.

The machine should be mounted in front of medium-sized standard tractors (minimum 60kW). In the crop season the harvester will allow to make the harvest of ligneous biomass possible and in the residual period it may be used as a stationary chipper of branches and logs. The cutting and billeting units are PTO driven. Alternatively the circular saws can be driven by hydraulic engines. The advantage of the larger particle size of billets in cut-and-billet system is that the material is easier to store and dry, because the piles are much more open to natural ventilation. On the other hand, the fuel is generally not suited for small-scale boilers. The $200 \mathrm{~mm}$ billets have to be re-chipped before they can be used as fuel. The cut-and-billet method is more economic, because billets dry much easier than chip. Furthermore, the billets can be used directly in the singlefamily housing for heating destinations.

\section{Prototypes of cut-and-chip harvesters}

The results of cooperation of Rzeszow University of Technology and SIPMA joint-stock company, one of the leading manufacturer of agricultural machines in Poland are a series of harvesters for short rotation willow coppice. The both of one-row (Fig. 3a-b) and two-rows (Fig. 4a) harvesters are a side-operating and tractor-pulled single-pass cut-and-chip harvesters. The harvester should be accompanied by an additional, separate tractor-trailer combination to collect the chips. The machines are destined to work on the plantations where the rows are planted at $0.75 \mathrm{~m}$ between rows. The header attachment for the "HERO" series harvesters uses circular saws mounted in a horizontal plane to cut short rota- 
tion crops. The circular saws (Fig. 4b) with diameter of $0.4 \mathrm{~m}$ are driven by the HPL MA2 hydraulic engines controlled by electric-hydraulic distributor. The hydraulic engine drive of saws is a much simpler than structure of the mechanical gears that transmitted the power from power-take-off (PTO) to circular saw. Hydraulic drive is characterized by high flexibility that fully eliminates failures due to overloading of the cutting head. Operating speed of the machine is $6 \mathrm{~km} \mathrm{~h}^{-1}$ and the rotational speed of the circular saw is equal to $n=2100 \mathrm{rev} \cdot \mathrm{min}^{-1}$. Use cutting system with carbide-tipped circular saw blades not lead to negative tearing fibrous tissue and bark of stems (Fig. 5). However the carbide blades were vulnerable to rocks and had to be replaced after approximately 10 ha [4]. Feeder drums located vertically over the saw blades rotate at approximately $160 \mathrm{rev} \cdot \mathrm{min}^{-1}$ to actively collect and feed the crop back into the harvester's throat. The header has four horizontally mounted feed rollers (Fig. 6) that help feed cut stems back into the chipping unit. The two front rear feed rollers in the header grab the crop and draw it back toward the feed roller module of the harvester. The lower front feed roller in the header has deep paddles on it to help flip the base of each stem up into the two feed rollers behind it that are spring loaded. The harvesters are equipped with a PTO driven drum type chipper. Four knives are mounted on the rotor.

Many elements of both single- and double-row machine are hydraulically driven, i.e.: - the discharge pipe tilt mechanism,

- the lid tilt mechanism,

- the system of angular adjustment of bar position,

- the control system of cutting height,

- circular saw drive.

All the mentioned mechanisms are controlled by waterproof mobile control panel located in the cab.

a)

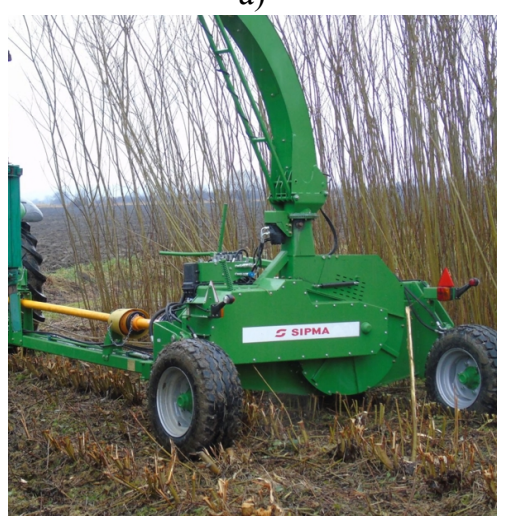

b)

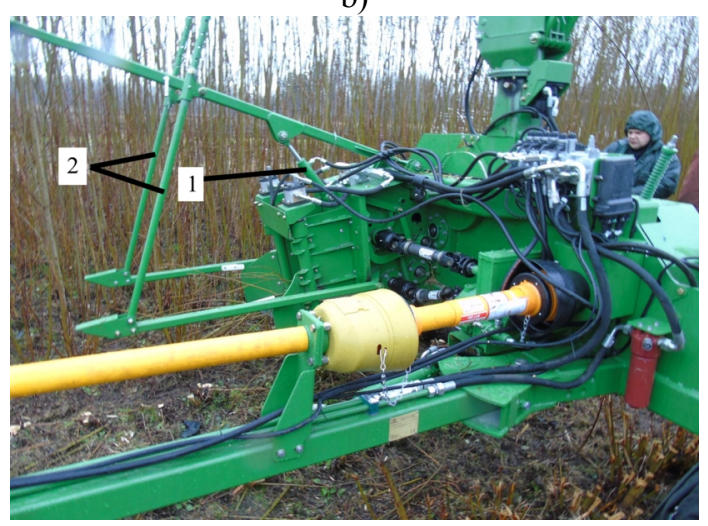

Fig. 3. Prototype of one-row side-operating SIPMA SR 1010 HERO harvester: a) back view, b) front view

Rys. 3. Prototyp jednorzędowego kombajnu bocznego SIPMA SR 1010 HERO: a) widok od tyłu, b) widok z przodu 
a)

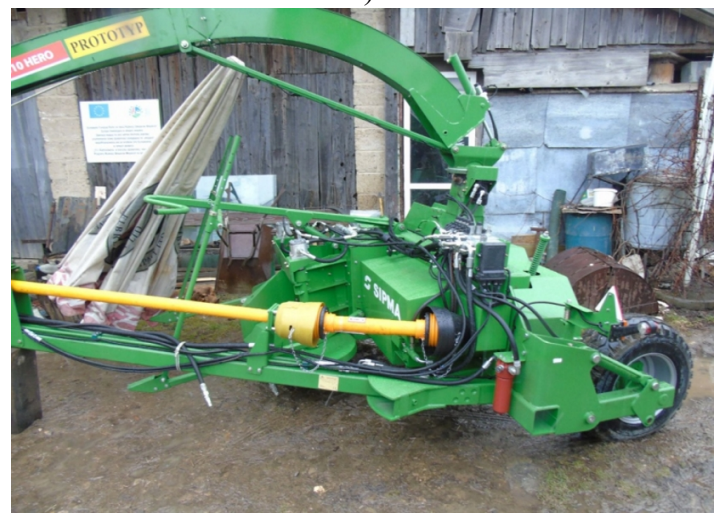

b)

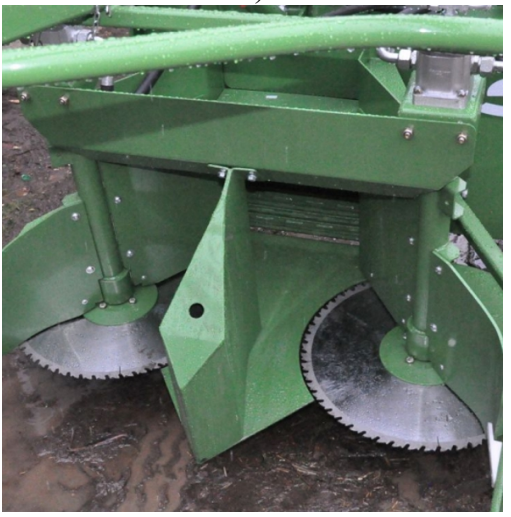

Fig. 4. Prototype of two-rows side-operating SIPMA SR 2010 HERO harvester (a) and cutting system (b)

Rys. 4. Prototyp dwurzędowego kombajnu bocznego SIPMA SR 2010 HERO (a) i moduł tnący (b)

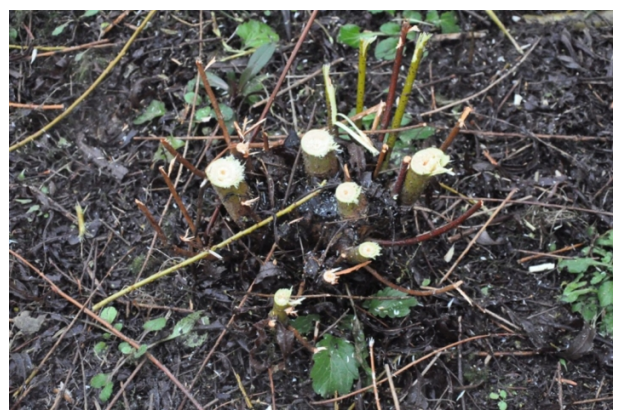

Fig. 5. View of the cut shoots

Rys. 5. Widok ściętych pędów

a)

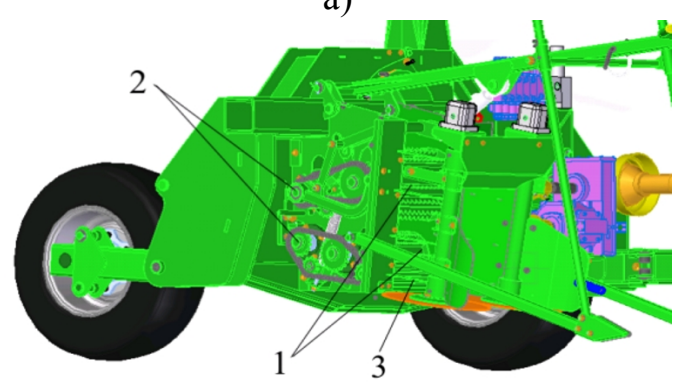

b)

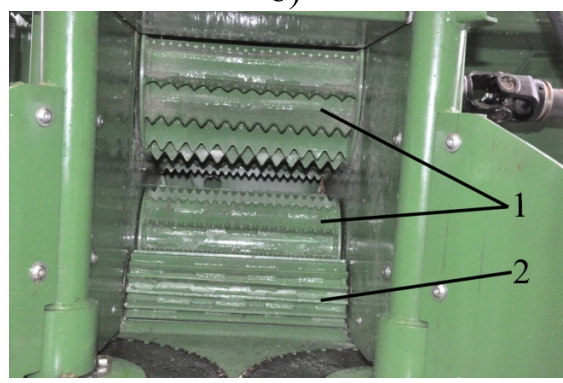

Fig. 6. Drive mechanism (a) and woody crop feeding system (b) of SIPMA "HERO" serie harvesters: 1 - chain transmission, 2 - rear feedrolls, 3 - upper fore feedroll, 4 - lower rear feedroll Rys. 6. Mechanizm napędowy (a) i system zbioru i cięcia drewna (b) kombajnu serii SIPMA "HERO": 1- przekładnia łańcuchowa, 2 - rolki podajnika, 3 - przednie górne rolki, 4 - dolne tylne rolki 
Chip size distribution is therefore the best indicator of how a chipper performs in terms of product quality [15]. The polish standard PN-91/D-95009 [12] determines the terms of chips harvesting in polish forests. The chips humidity is not standardized. Fuel wood chips dimensions are limited to $50 \mathrm{~mm}$, however not less than $90 \%$ of the chips should not exceed $40 \mathrm{~mm}$ in size. In the case of storage, too excessive fragmentation of chips in combination with high humidity is disadvantageous because of the possibility of the digestion of stored chips. The presence of oversize particles may prevent use in small and mediumsize plants, those that generally offer the best price opportunity [2]. Hovewer, very fine chips are known to store poorly [15]. The size distribution of the willow chips (Fig. 7) meet the geometric requirements of fuel wood chips. The major fraction of crop are chips with length of about $35-45 \mathrm{~mm}$. This confirmed the proper synchronization of feeding speed and rotational speed of the drum chipper.

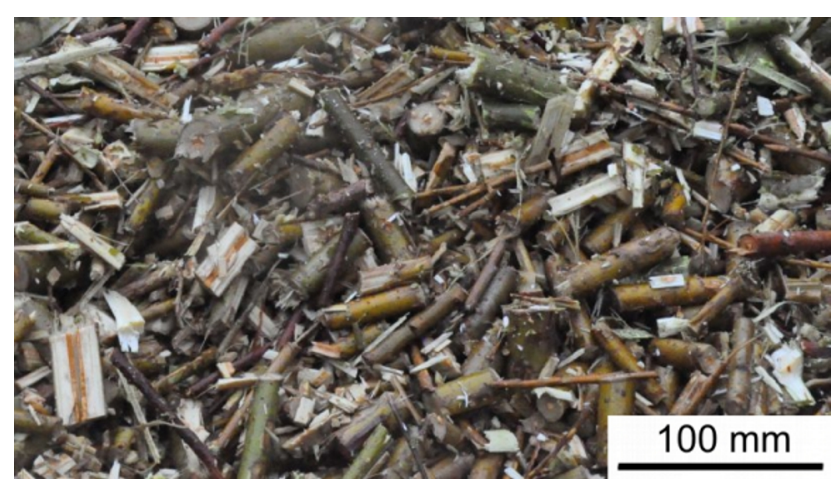

Fig. 7. Example of wood chips from willow harvested with the prototype

Rys. 7. Przykład zrębek z wierzbiny zebranej z prototypem kombajnu

The field tests confirmed that prototypes of willow harvesters meet the main design guidelines, i.e.:

- machines provide handling of at least 3 year-old willow with maximal stem diameter of shrub equals of $70 \mathrm{~mm}$,

- to drive the harvesters required tractor power does not exceeded approximately $120 \mathrm{~kW}$,

- the drum type chipper can produce chips that are up to 35-50 mm long,

- effective material capacity is equal to $30 \mathrm{Mg}$ per hour,

- prototypes should meet the requirements of road traffic act,

- the performance objectives of the harvesting platform include the ability to harvest willow coppices containing stems up to $120 \mathrm{~mm}$ in diameter,

- harvesters are equipped in centrifugal discharge pipe allowing directional transport of chips at the distance of $5 \mathrm{~m}$ into a trailer. 


\section{Summary}

Machines destined for operation in small and medium-sized plantations of energetic plants are characterized by simple construction and they do not require highly skilled workers. In the case of establishing, protective treatments, logging and processing of the biomass in plantation of the energetic plants the farm tractors are basic prime mowers of specialized machines. The prototypes of machines developed by SIPMA S.A. and R\&D Centre Inventor Sp. $\mathrm{z}$ o.o are mounted at the back of a typical farm tractor and the chipping unit is PTO driven. The width both of prototypes meet the requirements of road traffic act. The circular saws are driven by the hydraulic engines controlled by electric-hydraulic distributor. The hydraulic engine drive of saws is a much simpler than structure of the mechanical gears that transmitted the power from PTO to circular saw. Furthermore, hydraulic drive is characterized by high flexibility that fully eliminates failures due to overloading of the cutting head. Because the speed of tractor-machine arrangement can be changed depending on the field conditions, therefore, the use of a hydraulic engine controlled by electrichydraulic distributor, will allow for optimum selection of the saws angular velocity so that the circumferential speed is higher than the speed of the farm tractor.

\section{Literatura}

[1] Berhongaray G., Kasmioui O.E., Ceulemans R.: Comparative analysis of harvesting machines on an operational high-density short rotation woody crop (SRWC) culture: One-process versus two-process harvest operation, Biomass and Bioenergy, vol. 58, 2013, pp. 333-342.

[2] Hakkila P.: Forest chips as a fuel for heating plants in Finland, Folia Forestalia Polonica, no. 586, 1984, pp. 1-62.

[3] Kofman D.K.: Harvesting short rotation coppice willow, Harvesting, no. 29, 2012, pp. 1-4.

[4] Lechasseur G., Savoie P.: Cutting, bundling and chipping short-rotation willow. Paper No. 05-080, 2005. http://www.csbe-scgab.ca (dostęp 05.03.2015)

[5] Niemiec W., Stachowicz F., Szewczyk M., Trzepieciński T., Production technology and management of energetic plants with lignified shoots. Econtechmod: An International Quaterly Journal on Economics of Technology and Modelling Processes, vol. 1, no 2, 2012, pp. 31-34.

[6] Niemiec W., Stachowicz F., Trzepieciński T.: New ways in harvesting and processing of woody biomass, Proceedings of 6th International Symposium on Exploitation of Renewable Energy Sources and Efficiency, March 27-29, Subotica, 2014, pp. 58-61. 
[7] Niemiec W., Stachowicz F., Szewczyk M., Trzepieciński T.: Technological progress in production, logging and processing of the biomass, SSP - Journal of Civil Engineering, vol. 6, no. 2, 2011, pp. 85-92.

[8] Niemiec W., Skiba S., Ślenzak W.: Wood cutter, utility model W-116926, 2007 (in Polish).

[9] Niemiec W., Skiba S., Stachowicz F.: Feeding assembly for wood cutter, utility model W-119154, 2010 (in. Polish).

[10]Niemiec W., Skiba S., Stachowicz F., Trzepieciński T.: Harvester for crop and chipping of ligneous stems of energy plants and branches, utility model W-119895, 2011 (in Polish).

[11]Niemiec W., Stachowicz F., Szewczyk M., Trzepieciński T.: Technology of biomass utilization in small-sized farms, Zeszyty Naukowe Politechniki Rzeszowskiej. Budownictwo i Inżynieria Środowiska, z. 59, nr 283, 2012, s. 493-500 (in Polish).

[12] PN-91/D-95009 - Raw wood. Forestry chips (in Polish).

[13] Schweier J., Becker G.: Harvesting of short rotation coppice - harvesting trials with a cut and storage system in Germany, Silva Fennica, vol. 46, 2012, pp. 287-299.

[14]Schweier J., Becker G.: New Holland forage harvester's productivity in short rotation coppice: Evaluation of field studies from a German perspective, International Journal of Forest Engineering, vol. 23, no. 2, 2012, p. 82-88.

[15] Spinelli R., Hartsough B.R., Magagnotti N.: Testing mobile chippers for chip size distribution, Journal of Forest Engineering, vol. 16, no. 2, 2005, pp. 29-35.

[16] Spinelli, R., Nati, C., Magagnotti, N.: Harvesting short-rotation poplar plantations for biomass production, Croatian Journal of Forest Engineering, vol. 29, 2008, pp. 129-139.

[17] Spinelli R., Nati C., Magagnotti N.: Using modified foragers to harvest shortrotation poplar plantations, Biomass Bioenergy, vol. 33, no. 5, 2009, pp. 817-821.

[18]Trzepieciński T., Niemiec W., Stachowicz F.: Wybrane problemy projektowania kosiarek do ścinania drzewiastych roślin i pielęgnacji terenów zieleni, Technika Rolnicza Ogrodnicza Leśna, nr 1, 2013, s. 13-15.

[19]Wickham J., Rice B., Finnan J., McConnon R.: A review of past and current research on short rotation coppice in Ireland and abroad, Coford, Dublin 2010.

\section{Acknowledgment}

The research leading to these results has received funding from the Operational Programme - Innovative Economy 2007-2013 within the measure 1.4 "Support for implementation of results of $R \& D$ works". 


\section{MALOSKALOWE MASZYNY DO ZBIORU PLONU Z ZAGAJNIKÓW WIERZBY O KRÓTKIEJ ROTACJI}

\section{Streszczenie}

Mechanizacja zbioru plonu z zagajników wierzby o krótkiej rotacji jest warunkiem wstępnym do rozrastania się powierzchni upraw o krótkiej rotacji. W artykule przedstawiono nowe maszyny przeznaczone dla małych obszarowo plantacji roślin energetycznych. Prototypy maszyn zostały wyprodukowane przez firmy R\&D Centre INVENTOR sp. z o.o. and SIPMA S.A. z siedzibą w Lublinie we współpracy z Politechniką Rzeszowską. Zaletą proponowanych rozwiązań jest ich nieskomplikowana konstrukcja w połączeniu z niskim kosztem wytwarzania oraz prostotą obsługi. Maszyny do zbioru plonu z upraw energetycznych są konkurencyjne cenowo w stosunku do maszyn światowych producentów. Zespół rozdrabniający maszyn znajduje się z przodu lub z boku kombajnów i jest napędzany wałkiem odbioru mocy ciągnika. W skład głowicy ścinającej kombajnów wchodzą piły tarczowe napędzane silnikami hydraulicznymi. Przedstawiono również podstawowe parametry trzech prototypów maszyn.

Słowa kluczowe: zbiór biomasy, wierzba, kombajn, OZE, zagajnik o krótkiej rotacji

Przestano do redakcji:15.06.2015

Przyjęto do druku:1.12.2015

DOI: $10.7862 / \mathrm{rb} .2015 .157$ 